\title{
A Comparative Study of Fixatives for Axolotl Blastema Tissue
}

\author{
Estudio Comparativo de Fijadores para el Tejido Blastema del Axolotl
}

Ilknur Keskin ${ }^{1,4}$; Berna Yıldırım4; Bircan Kolbasi ${ }^{4}$; Gürkan Öztürk ${ }^{2,4}$ \& Turan Demircan ${ }^{3,4}$

KESKIN, I.; YILDIRIM, B.; KOLBASI, B.; ÖZTÜRK, G. \& DEMIRCAN, T. Comparative study of fixatives for axolotl blastema tissue. Int. J. Morphol., 35(1):47-51, 2017.

SUMMARY: Regeneration is defined as tissue renewal and functional restoration process of the damaged parts of the body after an injury. Ambystoma mexicanum, commonly named the Axolotl, is one of the unique vertebrates, which has a remarkable ability to regenerate their extremities following the amputation. Although the process of regeneration includes several periods, it can be divided into two main phases; blastema formation and dedifferentiation. In the couple of hours following the amputation, wound closure occurs by migration of epithelial cells around the amputation site followed by macrophage infiltration and dedifferentiation of cells to turn into stem cells. Accumulated stem cells form a very authentic tissue type called blastema, which is crucial for successful regeneration. In order to evaluate this exceptional tissue and acquire high quality images, it is crucial to employ specific procedures to prepare the tissue for imaging. Here, in this study, we aimed to investigate success of various fixative solutions (Carnoy's, Bouin's, \% 10 NBF, Clarke's, Alcoholic Formaline and AFA) to monitor the fixed blastema. Our data reveals that integrity of the blastema tissue differs among used fixatives and a significant difference is observed between the samples in terms of staining quality.

KEY WORDS: Axolotl; Blastema; Fixatives; Histology.

\section{INTRODUCTION}

Regeneration of tissues and organs is observed in all adult tetrapods in different extent, and among the vertebrates urodeles (newts and salamanders). Salamanders are fascinating animals capable of regenerating most of the internal organs, central nervous system as well as extremities throughout their lives (McCusker \& Gardiner, 2011). Tissue renewal and restoration capacity of salamanders makes them promising model to explore the mechanisms and molecular pathways that have roles in regeneration (Voss et al., 2015). A commonly used salamander species, Axolotl (Ambystoma mexicanum), has lifelong lasting neoteny and does not undergo metamorphosis naturally. Therefore, it can maintain its remarkable regeneration capacity in adult stage and this feature promotes its broad utilization in regeneration studies.

Formation of blastema tissue is a crucial step in regeneration following an amputation or an injury. This unique tissue consists of stem/progenitor cells as a consequence of dedifferentiation and accumulation events, which take place at the cut or wound site. In this phase of regeneration, migration of epidermal cells to form wound epithelium, immune response, proliferation of dedifferentiated stem/progenitor cells and eventually growth of blastema are observed (McCusker et al., 2015). To extend our current understanding on cellular and structural composition of blastema, preservation of cells and components as they naturally occur is essential. The key step of histological analysis of a tissue needs a proper fixation method and consequently availability of appropriate fixatives for that purpose. A proper fixative fluid should fulfill the following criteria: 1) prevention of autolysis, 2) preservation of structures between and 3) within the cells and inhibition of contamination by bacterial or molds growth (Perry et al., 2016). Therefore, comparison of various fixative solutions for blastema tissue in order to choose the proper one for the desired purpose would offer valuable information to utilize in histological evaluation in regeneration studies.

\footnotetext{
${ }^{1}$ Department of Histology and Embryology, School of Medicine, Istanbul Medipol University, Istanbul, Turkey.

${ }^{2}$ Department of Physiology, International School of Medicine, Istanbul Medipol University, Istanbul, Turkey.

${ }^{3}$ Department of Medical Biology, International School of Medicine, Istanbul Medipol University, Istanbul, Turkey.

${ }^{4}$ Regenerative and Restorative Medicine Research Center, REMER, Istanbul Medipol University, Istanbul, Turkey.
} 
In this study, various fixative solutions were investigated to test the success of fixation of the blastema. Blastema tissues at day 4 post-amputation were obtained from forelimbs of the animals and these tissues were fixed in tested fixatives according to their suggested protocols. Due to these fixatives (Carnoy's, Bouin's, \%10 NBF, Clarke's, Alcoholic Formaline and AFA (Alcohol, formaline and acetic acid) widely use in routine histological/immunohistological staining procedures, we chose them to test for blastema tissue as well. Fixation with assayed fixative solutions is followed by Hemotoxylin \& Eosin, Masson's trichrome staining and anti-Tubulin immuno-labeling. According to our results, the most insightful data were obtained by using Bouin's and AFA fixatives. By employing Alcoholic Formaline and AFA, a moderate quality of preservation of tissue and staining were acquired. Preservation degree of the blastema tissues was very poor for commonly used fixative for blastema, $\% 10 \mathrm{NBF}$. By applying Carnoy's solution, fixation of blastema was not succeeded. Immuno-labeling results demonstrate that the finest staining was obtained with NBF and AFA fixatives. Based on our results, we strongly believe that the obtained data will be widely utilized for during detailed evaluation of blastema tissue for further research.

\section{MATERIAL AND METHOD}

Experimental protocols and animal care conditions were authorized by the local ethics committee of the Istanbul Medipol University (IMU) with the approval number 38828770-E.4652. Adult axolotls $(12-15 \mathrm{~cm}$ in length) obtained from animal care facility of the IMU were used for these experiments. Maintenance of animals was provided in individual aquaria at $18{ }^{\circ} \mathrm{C}$ in Holtfreter's solution. Animals were anesthetized using $0.1 \%$ benzocaine (Sigma) before the amputation of right forelimb and sampling of 4 days blastema. Obtained blastemal samples were fixed in six different freshly prepared fixative solutions according to manufacturer's protocols (Suvarna et al., 2013). Fixatives used in this study are; $\% 10$ NBF (a.k.a. $4 \%$ aqueous solution of formaldehyde), Alcoholic Formaline, AFA, Bouin's, Carnoy's and Clarke's solutions [recipes of these fixatives are described in Suvarna et al.]. Following the fixation, blastema samples were embedded to paraffin and sectioned in $4 \mu \mathrm{m}$ thick sections by using a microtome (Thermo Scientific, HM 340E). For histological analysis, paraffin sections of blastema tissues were stained with Hematoxylin\&Eosin (Bio-Optica Mayer's Hematoxylin and Eosin Y Plus) and Masson's Trichrome (Bio-Optica, 04 - 010802) according to manufacturer's protocols. Stained sections were covered with mounting medium and analyzed under a light microscope by using Nikon DS-Fi2-U3 Digital Camera and its image analysis software system. Immunofluorescence staining was performed withalpha-Tubulin primary antibody $(1: 100$, rabbit; Sigma, T3526) and goat-anti rabbit 488 (1:200, Life Technologies, A-11008) secondary antibodies as described before (Suvarna et al.). DAPI (Life Technologies, P36931) was used to label the nucleus for counterstaining. For imaging, LSM 780 NLO Multiphoton confocal microscope (Zeiss) was used.

\section{RESULTS}

In this study, the suitability of applied fixatives for histological analysis of blastema tissue is demonstrated based on the observed differences in fixation and staining grades.

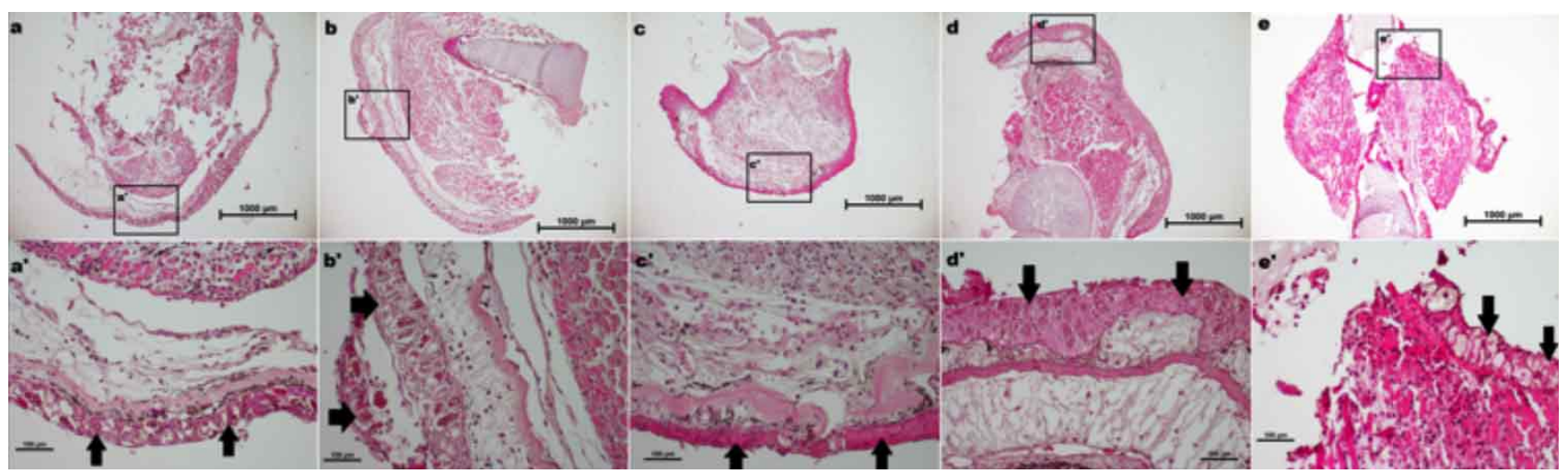

Fig. 1. Histomorphological assessment of different fixatives on axolotl blastema. Blastema tissue sections were stained with hematoxylin and eosin (H\&E). Samples were fixed with NBF (a,a'), Alcoholic Formaline (b,b'), AFA (c,c'), Bouin's (d,d'), Carnoy's and Clarke's (e,e') solutions. Black arrows show epithelial tissue. 4X magnification, Bar=1000 $\mu \mathrm{m}(\mathrm{a}, \mathrm{b}, \mathrm{c}, \mathrm{d}, \mathrm{e})$ and $20 \mathrm{X}$ magnification, Bar=100 $\mu \mathrm{m}$ $\left(a^{\prime}, b^{\prime}, c^{\prime}, d^{\prime}, e^{\prime}\right)$ 
During the analysis of the histological structure of the blastema tissue following the Hematoxylin \& Eosin staining, tissue disruption and loss of cellular integrity are observed for the samples fixed with NBF (Fig. 1a) and Clarke's (Fig. 1e) solutions. There are impairments around the border of epithelium with NBF fixed blastema tissue (Fig. 1a). On the contrary, the tissues fixed with AF (Fig. 1b), AFA (Fig. 1c) and Bouin's (Fig. 1d) reagents maintain the integrity of the tissue structure. Obvious nucleus and the boundary of the cells can be noticed for the slides of AF, AFA and Bouin's samples (Figure $1 \mathrm{~b}, \mathrm{c}, \mathrm{d}$ ). Similar results are obtained for Masson trichrome staining (Fig. 2). We could not slice the blastema samples which were fixed with Carnoy solution. Hence, it is excluded from the inspected fixatives list. Based on the quality of staining in terms of brightness and sharpness, all fixatives except Clarke's solution demonstrate a good level of staining (Figs 1 and 2). As shown in (Fig. 1e and Fig. 2e), intense staining of the blastema samples complicates the evaluation of cellular structures.

Immunofluorescent staining results indicate that the pronounced labeling is observed for the slides of tissues fixed with NBF and AFA solutions (Figs. 3a,c). For the samples fixed with Clarke's reagent, clear labeling of tubulin is noticed (Fig. 3e). For the blastema samples fixed in AF solution, labeling is barely detectable (Fig 3b). Bouin's solution gives rise to non-specific staining (Fig. $3 d$ ). We did not obtain any signals for negative controls (Figs. 3a'-e').

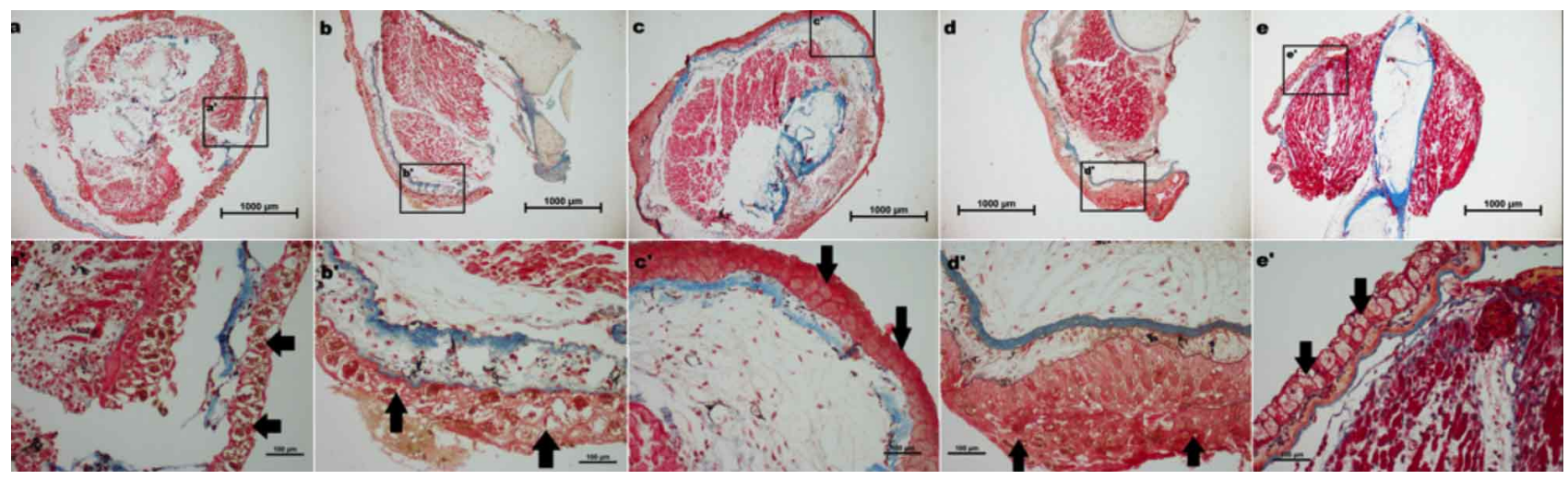

Fig. 2. Histomorphological assessment of different fixatives on axolotl blastema. Blastema tissue sections were stained with Masson's Trichrome after fixation in NBF (a,a), Alcoholic Formaline (b,b), AFA (c,c), Bouin's (d,d), Carnoy's and Clarke's (e,e') solutions. Black arrows demonstrate epithelial tissue. 4X magnification, Bar=1000 $\mu \mathrm{m}$ (a,b,c,d,e) and 20X magnification Bar=100 $\mu \mathrm{m}$ (a,b,c,d,e).

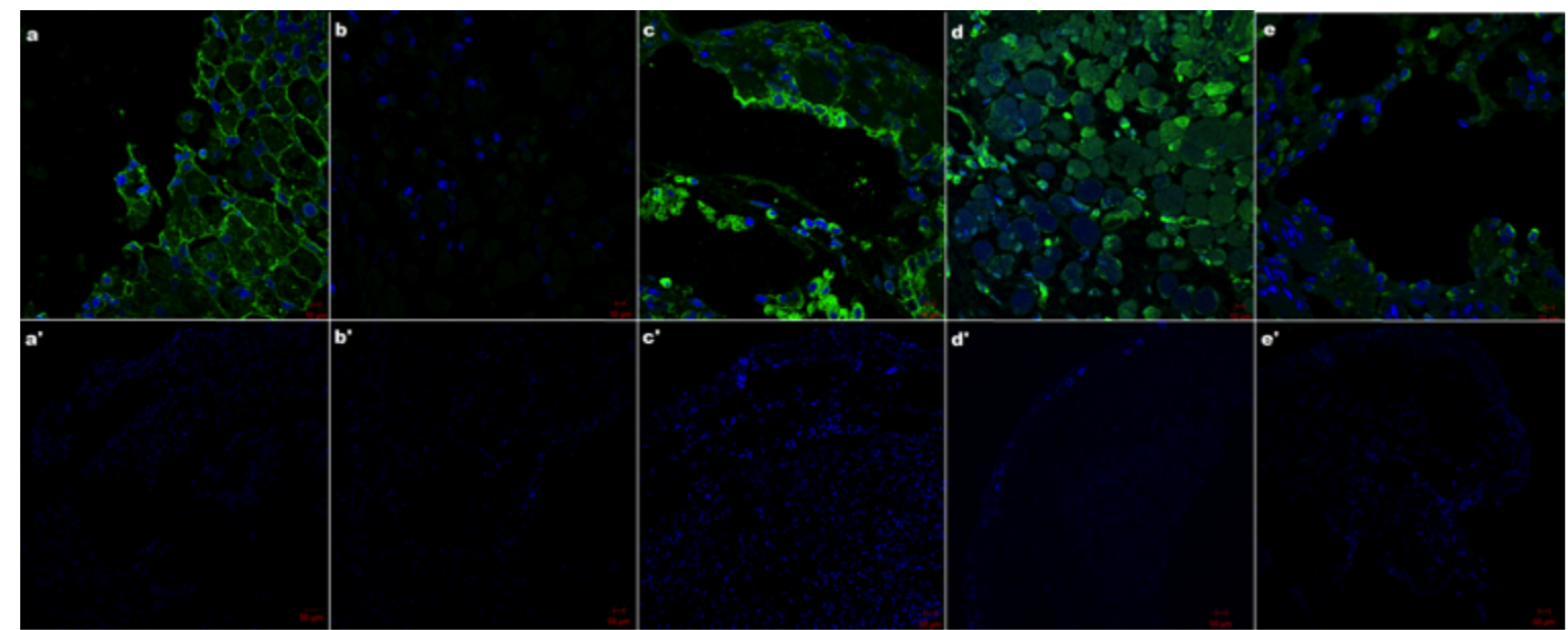

Fig. 3. Immunohistochemical staining of Tubulin after fixation with NBF, Alcoholic Formaline, AFA, Bouin's, Carnoy's and Clarke's solutions.40X magnification, $\mathrm{Bar}=10 \mu \mathrm{m}(\mathrm{a}, \mathrm{b}, \mathrm{c}, \mathrm{d}, \mathrm{e})$ and 10X magnification, Bar=50 $\mu \mathrm{m}$ (a,b,c,d,e) (blue; DAPI green; Tubulin). 


\section{DISCUSSION}

Following dissection from the organism, the tissues began to autolysis due to the catabolic enzymes that they contained. In the meantime, epithelium separates from the basement membrane and initiates pouring as a consequence of autolysis. The goal of incubation in a fixative solution is to maintain the structures of the samples as in living conditions. Using an appropriate fixative followed by histochemical / immunohistochemical staining is the key step to obtain the best possible and accurate visualization. Thus, during the staining processes, preservation of structural and chemical integrity by prevention of disintegration of tissues and cellular network is crucial. In addition to structural integrity, level of staining quality is associated to type of applied fixative. Furthermore, various fixatives have diverse effects on degradation of cellular components, proteins and nucleic acids. Considering the importance of immunological analysis and DNA/RNA labeling, protection of intracellular components is another essential selection criteria to use a fixative in routine applications. For aforementioned reasons, all fixatives may not be suitable for all tissues and staining methods.

It has been suggested that NBF can be utilized for routine fixation of any kind of samples (Suvarna et al. \& Grizzle, 2009) since it offers a durable fixation period and the suitability for many diverse stains as well as immunohistochemistry. Although high quality immunestaining results are acquired, our data suggest that NBF is not a proper fixative for histological analysis of blastema tissue. Alcoholic formalin is especially appropriate for fixation of polysaccharides (Hoda et al., 2016). According to our results, integrity of blastema tissues is maintained by its usage in histological analysis. Low levels of signals in immunofluorescence labeling might be due to limited preservation of antigens in blastema tissue fixed with Alcoholic formalin. AFA is a hybrid fixative and has the favorable features of consisting alcohol such as exceptional antigen conservation for post fixation processes. Moreover, on top of high grade protein conservation, preservation quality of nucleic acids in AFA makes it a commonly used fixative in wide range of histological examinations (Nietner et al., 2012). Our data reveal that AFA is the most suitable fixative for blastema tissue to perform histological and immune-histological staining. On the other hand, Bouin's Solution is suitable especially for small, soft and delicate tissues and is recommended for connective tissue (Ho?da et $a l$.). Based on our results, we conclude that, cytoplasm and nucleus are stained well with $\mathrm{H} \& \mathrm{E}$ and Masson trichrome staining following the fixation with Bouin's solution. According to the previous study (Prentø \& Lyon, 1997),
Clarke's solution is the most proper fixative for all rat tissues (spleen, stomach, liver, kidney, duodenum). However, for Axolotl blastema, we could not obtain adequate results regarding the cellular components. According to the literature, Carnoy' solution can be used in various tissues for histological studies due to its rapid penetration, preservation of nucleic acids and good fixation of glycogen and plasma cells (Pereira et al., 2015). In this study, since the samples fixed with Carnoy's solution could not be sliced, it has not been compared to the rest of the examined fixatives. Taken together, our data demonstrate that AFA is the most appropriate fixative for both histological and immunohistological analysis for Axolotl blastema tissue.

KESKIN, I.; YILDIRIM, B.; KOLBASI, B.; ÖZTÜRK, G. \& DEMIRCAN, T. Estudio comparativo de fijadores para el tejido blastema del axolotl. Int. J. Morphol., 35(1):47-51, 2017.

RESUMEN: La regeneración se define como la renovación del tejido y el proceso de restauración funcional de las partes dañadas del cuerpo después de una lesión. Ambystoma mexicanum, comúnmente llamado Axolotl, es uno de los únicos vertebrados que tiene una notable capacidad para regenerar sus miembros después de una amputación. Aunque el proceso de regeneración incluye varios períodos, se puede dividir en dos fases principales: formación del blastema y desdiferenciación. En el par de horas después de la amputación, el cierre de la herida ocurre por la migración de células epiteliales alrededor del sitio de la amputación seguido por una infiltración de macrófagos y la desdiferenciación de las células para convertirse en células madre. Las células madre acumuladas forman un tipo de tejido muy diferenciado denominado blastema, que es crucial para una exitosa regeneración. Para evaluar este tejido y adquirir imágenes de alta calidad, es crucial emplear procedimientos específicos para la obtención de imágenes. En este estudio, se intentó investigar el éxito de varias soluciones fijadoras (Carnoy, Bouin, \% 10 NBF, Clarke, Formalina Alcohólica y AFA) para monitorear la fijación del blastema. Nuestros datos revelan que la integridad del tejido del blastema difiere entre los fijadores utilizados y una diferencia significativa observada entre las muestras se da en términos de la calidad de tinción.

PALABRAS CLAVE: Axolotl; Blastema; Fijadores; Histología.

\section{REFERENCES}

Grizzle, W. E. Special symposium: fixation and tissue processing models. Biotech. Histochem., 84(5):185-93, 2009.

Hoda, M. K.; Klimek-Piotrowska, W.; Koziej, M.; Pia tek, K. \& Ho?da, J. Influence of different fixation protocols on the preservation and dimensions of cardiac tissue. J. Anat., 229(2):334-40, 2016.

McCusker, C. \& Gardiner, D. M. The axolotl model for regeneration and aging research: a mini-review. Gerontology, 57(6):565-71, 2011. 
McCusker, C. D.; Athippozhy, A.; Diaz-Castillo, C.; Fowlkes, C.; Gardiner, D. M. \& Voss, S. R. Positional plasticity in regenerating Amybstoma mexicanum limbs is associated with cell proliferation and pathways of cellular differentiation. B. M. C. Dev. Biol., 15:45, 2015.

Nietner, T.; Jarutat, T. \& Mertens, A. Systematic comparison of tissue fixation with alternative fixatives to conventional tissue fixation with buffered formalin in a xenograft-based model. Virchows Arch., 461(3):259-69, 2012.

Pereira, M. A.; Dias, A. R.; Faraj, S. F.; Cirqueira, C. dos S.; Tomitao, M. T.; Nahas, S. C.; Ribeiro, U. Jr. \& de Mello, E. S. Carnoy's solution is an adequate tissue fixative for routine surgical pathology, preserving cell morphology and molecular integrity. Histopathology, 66(3):38897, 2015.

Perry, C.; Chung, J. Y.; Ylaya, K.; Choi, C. H.; Simpson, A.; Matsumoto, K. T.; Smith, W. A. \& Hewitt, S. M. A buffered alcohol-based fixative for histomorphologic and molecular applications. J. Histochem. Cytochem., 64(7):425-40, 2016.

Prento, P. \& Lyon, H. Commercial formalin substitutes for histopathology. Biotech. Histochem., 72(5):273-82, 1997.

Suvarna, K. S.; Layton, C. \& Bancroft, J. D. Bancroft's Theory and Practice of Histological Techniques. 7th ed. Oxford, Churchill Livingstone Elsevier, 2013. pp.654.

Voss, S. R.; Palumbo, A.; Nagarajan, R.; Gardiner, D. M.; Muneoka, K.; Stromberg, A. J. \& Athippozhy, A. T. Gene expression during the first 28 days of axolotl limb regeneration I: Experimental design and global analysis of gene expression. Regeneration, 2(3):120-36, 2015.
Corresponding author:

Ilknur Keskin, MD, PhD.

Istanbul Medipol University

School of Medicine

Kavacik, Istanbul

TURKEY

Tel: +90-216-681-5100

E-mail: ilknurkeskin@medipol.edu.tr

Received: 25-06-2016

Accepted: 22-12-2016 